\title{
Nurse Managers' Competencies and its relation to their Leadership Styles
}

\author{
Nagwa Gouda Ahmed Abd-Elmoghith ${ }^{1} \&$ Takwa Rashawn Mohamed Abd-Elhady ${ }^{2}$ \\ 1. Assistant professor of the Nursing Administration, Faculty of Nursing Kafrelsheikh University, Egypt. \\ ${ }^{2 .}$ Lecturer of the Nursing Administration, Faculty of Nursing Port Said University, Egypt.
}

\begin{abstract}
:
The nurse manager offers crucial leadership for safe work, settings, and maintaining the best environment for achieving high quality of patients' outcomes, these to achieve the organizational objectives. The improvement of skills, that it is often underestimated, where the nurse managers are vital to success. Strive nursing leaders as providers during their job transfer from a clinical place. Aim of the study: To assess nurse managers' competencies and its relation to their leadership styles. Setting: This study was conducted at the Oncology Center, Mansoura University. A descriptive correlational research design was utilized. Subjects: The sample was composed of all nurse managers who are working during data collection $(n=65)$. Tools: 1$)$ Nurse Managers competency inventory (NMCI), and 2) Nurse Managers leadership styles. The results revealed that more than half of nursing managers demonstrate a high level of domain conduct daily unit operations, while, slightly less than half of study nurse managers had a low level of total competency and the higher mean scores of transformational leadership style were observed which the nurse manager always uses the idealized influence. The study concluded that there is a highly statistically significant relation between the nurse manager's competencies and the leadership style nursing managers. The study recommended that management, competency development introduced \& emphasized within the nursing curriculum; also an orientation management training program to be developed and conducted for new nurse managers regarding leadership, management functions and required skills, as well as how they deal with different situations.
\end{abstract}

\section{Keywords: Competencies, Leadership styles, \& Nurse Managers}

\section{Introduction:}

Nursing managers were identified as a key player in critical decision-making; and in the transformation of health care (Institute of Medicine of the National Academies, 2010). Scoble (2020) $\mid \&$ AONE (2019) further indicated that the nurse manager is responsible for coordinating and managing personnel, arranging nursing care, encouraging cooperation, assessing the services rendered, and leading to optimum outcomes for both the organization and the patients.

Nurse managers must be given appropriate and relevant knowledge, skills, and attitudes through leadership and management training to enable them to develop these critical competencies (Ofei., 2020). Nurse manager competencies have been recognized as key contributors to a healthcare organization's success (Groves, 2011). Also, Nurse managers the special competence area is structured using four categories as substantial knowledge, human resource management, operational management, and research and development (Kantanen., 2011). Thus nurse managers require knowledge and development to strengthen nursing manager's competence and leadership (Curtis, 2011 \& Fennimore \& Wolf, 2011).

Management competencies as a combination of skills, knowledge, attitude, and behavior that a person requires to be effective in a wide range of jobs, and various types of organizations, in addition, may be a source of sustained organizational performance (Gunawan \& Aungsuroch, 2017\& Manxhari., 2017 \& Gonzalez Garcia., 2020).

The competencies of the nurse manager are based on the learning domain structure; and capture the skills, cognitive and abilities that drive these nurse leaders' practice. The American Organization of Nurse Executives (2015) indicated that the effective nurse manager needs to acquire experience. In addition, Trivellas \& Reklitis (2014) indicate that managers equipped with high levels of leadership competencies were found to produce enhanced levels of job performance and job satisfaction. The influence of leadership competencies on individual effectiveness of managers is explored, providing a course for action toward managerial excellence.

Pillay (2011) stressed that core management competencies are essential for nurse managers' efficiency and effectiveness. In this regards, Bhardwaj \& Punia (2013) found that communication skills, team-working, proactiveness, vision, self-management, result-orientation, strategicorientation, ambition, persistence, decision making, risk taking and creativity, are the commonly used 
managerial competencies of successful and effective managers.

The nurse manager's competence is an important part of daily nursing practice. It is carried out in constantly changing circumstances which shape the management context, and which substantially affect the perception of the core mission of nursing leadership and management (Kantanen., 2017). Leadership is defined as a process in which an individual influences other individuals or a group to achieve a specific goal. Leaders and followers must understand each other because leaders and followers are part of this process, it is important to address issues facing followers as have also issued facing leaders (Northhouse, 2016).

Manxhari., et al (2017) pointed out that management skills are often said to be a collection of skills, experience, attitude, and actions that an individual needs in a broad variety of jobs, and different types of organizations to be successful. Also, (Wendler., et al (2009) Nursing leadership for achieving quality results requires advanced leadership skills to engage workers who accept improvement and analyses care practices consistently

Leadership theories focused on situational factors and the talents of leaders (Northouse, 2015). The nurse manager has a crucial leadership role to have safe work; settings, and good results for patients' outcomes, in addition to achievement of organizational objectives. The improvement of skills that is often underestimated, and new nurse managers are vital to success (Baxter \& Warshawsky, 2014).

\section{Significance of the study}

The improvement for administration competencies and leadership might strategically and systematically enhance all authoritative performances and essential management functions and will guide development and preparing and competent managers and leaders (Kakemam, 2020). The leaders in healthcare organizations have an understanding of the knowledge, abilities and skills which can ultimately be role-modeled and have a positive effect for these key role responsibilities, these fundamental competencies might make the building blocks for continuous improvement of nurse managers (Chase, 2010).

\section{Methodology:}

Research Design: descriptive correlational research design was used in the current study.

This study aims to: investigate the nurse managers' competencies and its relation to their leadership styles in the Oncology Center, Mansoura University

\section{Research Objectives:}

1.Determine levels of the nurse managers' competencies in the Oncology Center, Mansoura University

2.Assess leadership style of nurse managers in the Oncology Center, Mansoura University

3. Find out the relationship between the nurse managers' competency and their leadership style

Research questions:

1.What are the nurse managers' competency levels?

2.What is the leadership style of nurse managers?

3.Is there a relation between the nurse managers competency and leadership styles?

\section{Research Setting:}

The study was carried out all units in the oncology center in El Mansoura university, the center capacity is 20 units and 282 bed.

Consisted of eleven floors: oncology surgery unit ; oncology medical unit, medical and surgical intensive care units; and pediatric intensive care unit, children's oncology unit, operating room with its facilities, the outpatient clinics and reception, bone marrow transplant unit, emergency room, ambulatory care unit (one day surgery), optical endoscopy unit, unit of clinical pathology laboratories, the pharmacy, information systems unit, an oncology unit for early detection of abnormal cells ); in addition to physical and psychological rehabilitation \& pain treatment unit, and central services unit, sterilization department, blood bank, x-ray, chemotherapy room.

Study subjects:

The subject of the present study included all nurse managers how we're working during data collection at the Oncology Center - Mansoura University ( $\mathrm{n}=65)$ classified as (1) nurse director, (4) supervisors, (60) head nurse and charge nurse.

Charge nurse are permanent members of the nursing management team and are called shift supervisors.

Type of sample: Convenience sampling Tools of data collection:

Two tools were used to collect data for this study:

1. Nurse Managers' competency inventory (NMCI) developed by DeOnna (2006) this tool is used to assess nursing manager competency. It consist of 93 items classified into eleven competency domains namely: promote staff retention (12 items), recruit staff (10 items), facilitate staff development (11 items), perform supervisory responsibilities (14 items), ensure patient safety and quality care (5 items), conduct daily unit operations ( 8 items), manage fiscal planning (6 items), facilitate 
interpersonal group organizational communication (7 items), lead quality improvement initiatives ( 7 items), promote professional practice model (5 items), and develop self (8 items).

\section{Scoring system:}

The responses were preset according a 5-point Likert scale $(1=$ Not once to $5=$ Always). The total scores ranged from 93-465. It was categorized into three levels based on cut off point $50 \%$ as: low competency $<50 \%$ (scored from 93-278), moderate competency 50-75\% (279-372), and high competency > 75\% (373465).

1.Nurse Managers leadership style: prepared to assess leadership style of nurse managers. It was consisted of two parts:

- Demographic characteristic of nurse managers as "age, qualification, years of experiences..."

- Leadership styles tool that developed by Clark (1998) \& Elsayed (2005) to assess leadership styles. It is composed of 81 items; and two categories: traditional category; and advanced category.

I. Traditional category included 24 statements categorized under three divisions: Autocratic style: consisted of eight statements, democratic style: consisted of eight statements, lasses-fair style: consisted of eight statements.

II. Advanced category included 57 statements categorized under two major divisions "transformational and transactional".

- Transformational dimension consisted of 38 items divided into: Attributed charisma: include six items, idealized influence: consisted of nine items, inspirational motivation: consisted of seven items, intellectual stimulation: included eight items, individualized consideration: included eight items

- Transactional dimension contained 19 statements, divided into: Contingent reward: consisted of six statements, Active management by exception includes six items, Passive management by exception: consisted of seven items

\section{Scoring system:}

For leadership 81 items the responses were on a five Likert scale from "never" to "always" they were scored from 1 to 5 respectively for each statement. The score of each style was summedup; and the total was divided by the number of the items, giving a mean score for leadership style used. The highest mean score reflects the leadership style of the participant.

Validity and Reliability:

Validity: The tools were tested for its clarity, relevancy, applicability, understanding and ease of implementation by "five" experts of professors and assistant professors of nursing administration department.

The reliability of the two tools was tested using the internal consistency method. Cronbach's Alpha test for the reliability of nurse manager competency inventory was 0.931, and for leadership styles was 0.90 .

\section{Pilot study}

A pilot study was carried out with $10 \%$ of the sample size (7 nurse managers), to test the clarity of the questionnaire to estimate the time needed for data collection. The necessary modifications were done. Subjects who shared in the pilot study were excluded from the main study subjects.

Fieldwork:

Field work of the current study was executed in three months started at the end of August 2020 and was completed by the end of November 2020. The researcher met the respondents during at three days per week in three shifts to distribute the questionnaire. Data were collected from nurses in their work area. The preparatory phase was done by meeting with nurse managers to clarify the objective of the study, and applied methodology, then giving the instructions to fill in two questionnaires under guidance and supervision of the study researchers which ranged from 30 to 35 minutes.

\section{Administrative Design:}

An official letter was issued from the Dean of Faculty of Nursing at Kafrelsheikh University to the director of Mansoura University Oncology center to facilitate data collection and process of the research.

\section{Ethical Considerations:}

The researcher explained the aim of the research to nursing managers to get better cooperation during the data collection of the research. Also, oral consent was obtained from each participant. They were informed about their rights to refuse participation or withdraw at any time, without giving any reason. They were assured that all obtained information will be treated confidentially; and will only be used for the purpose of research. They were also reassured that the study maneuvers not entail any harmful effects on participants.

\section{Statistical analysis:}

All statistical analyses were performed using SPSS - version 20.0 (SPSS, Chicago, IL). Data were tested for normality of distribution prior to any calculations. All variables with continuous data showed normal distribution and were expressed in mean \pm standard deviation (SD). Categorical data were expressed in numbers and percentage. The correlation between variables with continuous data was evaluated by the correlation co-efficient test. Statistical significance was set at $\mathrm{p}<0.05$. 


\section{Results:}

Table (1): Distribution of personal characteristic of the studied nursing managers $(n=65)$

\begin{tabular}{|c|c|c|}
\hline & No. & $\%$ \\
\hline$\overline{\text { Age (years) }}$ & & \\
\hline$<30$ & 15 & 23.1 \\
\hline $30: 40$ & 45 & 69.2 \\
\hline$>40$ & 5 & 7.7 \\
\hline Mean \pm SD & \multicolumn{2}{|c|}{$34.4 \pm 5.3$} \\
\hline \multicolumn{3}{|l|}{ Educational } \\
\hline Bachelor & 55 & 84.6 \\
\hline Diploma & 5 & 7.7 \\
\hline Master & 5 & 7.7 \\
\hline \multicolumn{3}{|l|}{ Experience } \\
\hline $1 \leq 10$ & 20 & 30.8 \\
\hline $11: 20$ & 34 & 52.3 \\
\hline$>20$ & 11 & 16.9 \\
\hline Mean \pm SD & \multicolumn{2}{|c|}{$14.6+5.2$} \\
\hline Marital status & & \\
\hline Single & 10 & 15.4 \\
\hline Married & 52 & 80.0 \\
\hline Divorced & 3 & 4.6 \\
\hline
\end{tabular}

Table (2): Competencies levels of nurse managers in the study (n=65)

\begin{tabular}{|c|c|c|c|c|c|c|c|}
\hline \multirow{3}{*}{ Competency domains } & \multicolumn{6}{|c|}{ Frequency of NMCI grades } & \multirow{3}{*}{ Mean \pm SD } \\
\hline & \multicolumn{2}{|c|}{$\begin{array}{c}\text { Low } \\
\text { competency }\end{array}$} & \multicolumn{2}{|c|}{$\begin{array}{l}\text { Moderate } \\
\text { competency }\end{array}$} & \multicolumn{2}{|c|}{$\begin{array}{l}\text { High } \\
\text { competency }\end{array}$} & \\
\hline & No. & $\%$ & No. & $\%$ & No. & $\%$ & \\
\hline 1.Promote staff retention & 18 & 27.7 & 37 & 56.9 & 10 & 15.4 & $37.8+13.2$ \\
\hline 2. Recruit staff & 16 & 24.6 & 38 & 58.5 & 11 & 16.9 & $31.1 \pm 7.3$ \\
\hline 3. Facilitate staff development & 29 & 44.6 & 25 & 38.5 & 11 & 16.9 & $33.8 \pm 6.7$ \\
\hline 4.Perform supervisory responsibilities & 19 & 29.2 & 35 & 53.8 & 11 & 16.9 & $42.6 \pm 9.3$ \\
\hline 5.Ensure patient safety & 17 & 26.2 & 38 & 58.5 & 10 & 15.4 & $16.8 \pm 3.8$ \\
\hline 6. Conduct daily unit operations & 17 & 26.2 & 12 & 18.5 & 36 & 55.4 & $30.0 \pm 8.6$ \\
\hline 7. Manage fiscal planning & 15 & 23.1 & 24 & 36.9 & 26 & 40.0 & $21.1 \pm 4.8$ \\
\hline $\begin{array}{lll}\text { 8. Facilitate interpersonal } & \text { group } \\
\text { organizational communication } & \end{array}$ & 16 & 24.6 & 49 & 75.4 & 0 & 0.0 & $21.0 \pm 6.0$ \\
\hline 9. Lead quality improvement initiatives & 28 & 43.1 & 37 & 56.9 & $\overline{0}$ & 0.0 & $19.6 \pm 5.2$ \\
\hline 10. Promote professional practice model & 19 & 29.2 & 46 & 70.8 & 0 & 0.0 & $15.5+3.6$ \\
\hline 11. Develop self & 29 & 44.6 & 13 & 20.0 & 23 & 35.4 & $26.3 \pm 6.0$ \\
\hline Nurse manager competencies score & 30 & 46.2 & 24 & 36.9 & 11 & 16.9 & $295.5 \pm 58.7$ \\
\hline
\end{tabular}

Table (3): Mean scores of the nurse managers regarding leadership styles ( $n=65)$

\begin{tabular}{|l|c|c|}
\hline & Range & Mean \pm SD \\
\hline Autocratic style & $10-40$ & $22.7 \pm 8.9$ \\
\hline Democratic style & $20-40$ & $27.3 \pm 6.8$ \\
\hline Lasses fair style & $19-40$ & $27.5 \pm 6.8$ \\
\hline I. Total Traditional category scores & $61-120$ & $77.5 \pm 19.5$ \\
\hline Attributed charisma & $14-30$ & $22.4 \pm 5.8$ \\
\hline Idealized influence & $24-45$ & $32.9 \pm 7.9$ \\
\hline Inspirational motivation & $8-35$ & $22.2 \pm 8.5$ \\
\hline Intellectual stimulation & $12-40$ & $23.2 \pm 8.6$ \\
\hline Individualized consideration & $8-40$ & $26.1 \pm 11.3$ \\
\hline A.Transformational dimension total score & $82-190$ & $126.9 \pm 35.1$ \\
\hline Contingent reward & $6-30$ & $15.9 \pm 7.7$ \\
\hline Active management & $6-30$ & $17.8 \pm 7.9$ \\
\hline
\end{tabular}




\begin{tabular}{|l|c|c|}
\hline & Range & Mean \pm SD \\
\hline Passive management & $11-34$ & $21.1 \pm 6.1$ \\
\hline B. Transactional dimension total score & $23-94$ & $54.7 \pm 20.9$ \\
\hline II. Advanced Category total score & $109-284$ & $181.7 \pm 52.4$ \\
\hline
\end{tabular}

Table (4): Correlation between nurse managers' competencies and their leadership styles

\begin{tabular}{|c|c|c|c|c|c|c|}
\hline & \multicolumn{2}{|c|}{$\begin{array}{c}\text { Traditional } \\
\text { Category }\end{array}$} & \multicolumn{2}{|c|}{$\begin{array}{c}\text { Transformationa } \\
\text { I Dimension }\end{array}$} & \multicolumn{2}{|c|}{$\begin{array}{c}\text { Transactional } \\
\text { Dimension }\end{array}$} \\
\hline & $r$ & $p$ & $\mathrm{r}$ & $p$ & $r$ & $p$ \\
\hline Nurse Manager Competency levels & 0.868 & $<0.001$ & 0.975 & $<0.001$ & 0.921 & $<0.001$ \\
\hline Traditional Category & & & 0.820 & $<0.001$ & 0.845 & $<0.001$ \\
\hline Transformational Dimension & & & & & 0.963 & $<0.001$ \\
\hline
\end{tabular}

Table (1): As can be seen in The characteristics of the studied group, with an average age ranged from less than 30 to more than 40 years, with a mean age of from 11 to 20 years with a mean of $14.6 \pm \mathbf{5 . 2}$. The table also shows that $80 \%$ are married.

Table (2): Describes the competency levels of nurse managers; more than half of study nurse managers (55.4\%) have high level regarding the competency of the domain conduct of daily unit operations, most of management competency domains were in the moderate level. Regarding total scores, the table also shows $46.2 \%$ of the sample are in low level. Furthermore, Findings clarified that the competency domains were compared and significantly different to mean scores was put into evidence.

Table (3): Summarize the mean scores of the leadership styles. The mean scores regarding total traditional category score were $77.5 \pm 19.5$, while the mean score of advanced category's total score was $181.7 \pm 52.4$ with the higher mean scores of transformational leadership style $126.9 \pm 35.1$.

Table (4): Clarifies that a highly statistically significant relations between nurse manager competency levels and their different leadership styles $(\mathrm{p}<0.001)$.

\section{Discussion:}

The present study was carried out to assess nurse managers' competencies and its relation to their leadership styles among nurse managers who are working at the Oncology Center -Mansoura University. The study shows that less than two-thirds of the study sample were in age group thirty to forty years, most of them have bachelor's degree; while slightly more than half had years of experience ranged from eleven to twenty years, and most of them was married.

As the present study results revealed competency domains related to conduct daily unit operations was the highest competency level followed by manages fiscal planning in category high competency. This result might be due to the nurse managers who are working at the university hospital received training as part of a nursing program to help in successfully get experience and knowledge to provide quality of care, manage the budget and planning management.

These results are in agreement with Hagrass (2017) indicated that the competency domains which related to ensure patient safety \& conduct daily unit operations were ranked highest relation and MacLeod (2012) findings, which revealed that financial management is noted to be one of the key categories of competencies for nurse manager success. Similarly, Clark (2015) pointed out that financial and budgetary management' skills are a prerequisite for competent nurse managers. While; this disagreement with Hagrass (2017) who reported that competency domains, manage fiscal planning is rated as lowest competency.

This study has shown that performing supervisory responsibilities were founded the highest competency domain by nursing managers. These findings might be due to the nurse managers using management skills and practiced tools during work environment the long term. In consistence with Deonna (2006) who reported performing supervisory responsibilities was the highest competency domain by nurse managers. In the same line, Clay- Williams, (2018) indicated that the nurse managers required to provide direction for health care environment that stand up to the delivery of quality health care. In contrast, Fennimore \& Wolf (2011) reported that management competency is ensuring and quality care is vital to patient care that provided as well.

The findings of the present study indicated that slightly less than half of nursing managers had a low level of competency. This may be related to the frequency of performing managers' activities were low and this because of they were having a higher responsibility and loaded during the morning shift. However, it might be lack of confidence in their ability and lack self-belief. Additionally, small numbers of nursing managers showed a high frequency of performing activities related to selfimprovement or play a leadership role within this 
organization or in another organization. These are in agreement with Pillay (2009) findings who reported a lack of management competency within the public health sector in South Africa.

These results also are in contrast with As well, Ofei., (2020) \& Yang., (2014) findings reported that competency of nurse managers was in the moderate range Khodgaria (2011) who reported that more than two thirds of the study sample had moderate competency level, and they were proficient based on Benner's skill acquisition model which improved after training interventions to high level. In this respect, Stobinski (2011) indicated that a significantly higher mean scores on the overall competency levels was observed in the studied group.

Regarding transformational leadership style the findings of the present study indicated that the highest mean scores of which the nurse manager always use the idealized influence thus to influence their staff behaviors. These results might be due to the workplace itself as it may affect the nurse manager's ability to exercise transformational leadership behavior; and can be more attractive in the future. This findings are incongruent with Hussein (2009) who found that most transformational head nurses always use the idealized influence. Moreover, Raup (2008) found that transformational leadership behaviors are categorized as charismatic. In addition, these are in accordance with the findings of McGuire \& Kennerly (2006).

The present study findings indicated a highly statistically significant relationship between nurse managers competencies and leadership styles. These might be due to the nurse managers are required to support and select their role based on an expertise and leadership. Similar results obtained by Deyo. (2016) who mentioned that the nurse managers' competencies are affected by leadership competencies which can be adapted into successful nurse managers' competencies; in addition to the position as essential elements to collaborating with each other. On the same hand, Saleh. (2018) commented that the essential management competencies are very important for initiating and developing nurse leaders' competencies.

\section{Conclusion:}

Summing up the results, it can be concluded that the highest percent of nurse managers had a low level of competency, and the higher mean scores of transformational leadership style were observed which the nurse manager always uses the idealized influence to influence their staff behaviors. The study concluded there is a highly statistically significant relation between the nurse manager's competencies and the leadership style nursing managers who are working in Oncology Center, Mansoura University

\section{Recommendations:}

- Introduce management competencies during development of nursing students' curriculums.

- Nurse managers should update their leadership competencies through ensuring that things are done right, and transfer of adequate knowledge, skills, and competencies through directing the work of other staff, in addition to have control over the work performed, exercises; examination and evaluation of staff performance.

- Develop an orientation training program for nurse managers about leadership, management functions and skills, and how to deal with different situations.

- Provide opportunities for managers to practice leadership responsibilities and teach them how to use their interpersonal skills.

- Nurse Managers must be given appropriate and relevant knowledge, skills, and attitudes through leadership and management training to enable them to develop these critical competencies.

Acknowledgment: The researches would like to extend their thanks to Mansoura University Hospital Oncology center director and nurse managers for their participation in the current study.

\section{References}

- AONE American organization for nursing leadership (2019): Nurse Executive Competencies. Available online: http://www.aone.org/ resources/nurseleader-

- Baxter, C. \& Warshawsky, N. (2014): Exploring the Acquisition of Nurse Manager Competence. https://www.researchgate_.net/publication 1260213541 .

- Bhardwaj, A. \& Punia, B (2013): Managerial competencies and their influence on managerial performance: A literature review, International Journal of Advanced Research in Management and Social Sciences, Vol.(2) No.(5), Pp. 70-84.

- Chase, L (2010): Nurse manager competencies. University of Iowa. Clay-Williams, R., Johnson, A., Lane, P., Li, Z., Camilleri, L., Winata, T., et al. (2018). Collaboration in a competitive healthcare system: Negotiation 101 for clinicians. Journal of Health Organization and Management, Vol. (32) No. (2), Pp.263-278.Onlinehttps://doi.org/ 10.1108 /JHOM-12-2017-0333.

- Claessens, B., Van Eerde W., Rutte C., \& Roe R., (2007): A review of the time management 
literature, Personnel Rev, Vol. (36) No. (2), Pp.255-76.

- Clark, P. (2015): what budgetary skills do nurse managers need to success in a large healthcare setting published master. Thesis. The college of St, Scholastics, Dulluth, M N ProQuest publication: 161.

- Clark. D. (1998): Leadership style survey. Retrieved in Sept. 2020, from http://www.nwlink.com/ donclark/leader/survstyl. $\underline{\mathrm{html}}$

- Clay-Williams, R., Johnson, A., Lane, P., Li, Z., Camilleri, L., \& Winata, T., (2018): Collaboration in a competitive healthcare system: Negotiation 101 for clinicians, Journal of Health Organization and Management, Vol.(32)No.(2), Pp.263-278. https://doi.org/ 10.1108/JHOM-122017-0333.

- Curtis E, Sheerin F \& de Vries J (2011): Developing leadership in nursing: The impact of education and training. British Journal of Nursing Vol. (6), Pp.344-352.

- Deonna, J. (2006): developing and validating an instrument to measure the perceived job competencies linked to performance and staff retention of first line nurse manager employed in a hospital setting, Published Doctor of Philosophy, Thesis, the Pennsylvania State University,Pp. 68, 133-7.

- DeOnna. J. (2006): Developing and Validating an Instrument to Measure the Perceived Job Competencies Linked to Performance and Staff Retention of First-Line Nurse Managers Employed in a Hospital Setting, Thesis doctoral degree, Pp. 133 .

- Deyo, P. \& Swartwout, E. \& Drenkard, K. (2016): nurse manager competencies supporting patient engagement, JONA, Vol.(46) No.(35). Retrieved on January 4, 2021 from https://pubmed .ncbi.nlm .nih .gov /26906688/.

- Elsayed, K (2005): Leadership styles, empowerment, and job satisfaction among nursing leaders, Unpublished doctorate thesis, Nursing Administration, Faculty of Nursing, Ain Shams University, Egypt.

- Fennimore, L. \& Wolf, G. (2011): nurse manager leadership development leveraging the evidence and the system level support, The journal of nursing administration, Vol.(41) No. (5), Pp. 204210.

- Gonzalez Garcia, A., Pinto-Carral, A., Sanz Villorejo, J., \& Marqués-Sánchez, P. (2020): Nurse Manager Core Competencies: A Proposal in the Spanish Health System, International journal of environmental research and public health, Vol. (17) No. (9), Pp.3173.
- Groves K (2011): Talent management best practices: How exemplary health care organizations create value in a down economy. Health Care Management Review, Vol. (3), Pp. 227-240.

- Gunawan, J., \& Aungsuroch, Y. (2017): Managerial competence of first - line nurse managers: A concept analysis. International Journal of Nursing Practice, 1-7. https:// doi.org/10.1111/ijn.12502.

- Hagrass H. (2017): nursing managers' competency and their problem-solving styles at Mansoura University Hospital, Thesis in Nursing Administration, Faculty of Nursing, Mansoura University.

- Hussein, A (2009): relationship between leadership styles and span of control of the head nurses at Zagazig University Hospitals, Thesis, Master's in Nursing Administration. Unpublished, Faculty of Nursing Zagazig University.

- Institute of Medicine of the National Academies. The Future of Nursing: Leading Change, Advancing Health; Institute of Medicine of the National Academies: Washington, DC, USA, 2010; Vol. (40), pp. 1-4.

- Kakemam, E., Liang, Z., Janati, A., ArabZozani, M., Mohaghegh, B., \& Gholizadeh, M. (2020): Leadership and Management Competencies for Hospital Managers: A Systematic Review and Best-Fit Framework Synthesis. Journal of healthcare leadership, Vol. (12) No. (59).

- Kantanen, K., Kaunonen, M., Helminen, M., \& Suominen, T. (2017): Leadership and management competencies of head nurses and directors of nursing in Finnish social and health care. Journal of Research in Nursing, Vol. (22) No. (3), 228-244.

- Khodgaria, M., \& Vanaki, Z., \& Navipour, H., \& Vaezi, A., (2011): the effect of nursing management development program on clinical competency in coronary care unit, Behood Journal, Vol. (15) No.(1),Pp.40-50.

- Macleod, L. (2012): A Broader View of nursing leadership: Rethinking manager leader functions, Nurse leader, Vol. (10) No. (3),Pp. 57-61.

- Manxhari, M., Veliu, L., \& Jashari, J. (2017): Developing models of managerial competencies of managers: A review, International Journal of Economics, Commerce and Management, Vol. (4),Pp. 186-200.

- McGuire, E. \& Kennerly, S. (2006): nurse managers as transformational and transactional leaders, Nursing Economics, Vol. (24) No.(4),Pp.183\&184.Retrieved on January 4, 2021 
from $\quad$ https://www. nursingeconomics.net/ce/2008/article08179186.pdf

- Northhouse, P. (2012): Introduction to leadership concepts and practice. 2nd edition. Retrieved from tps://books.goohtgle.com.sa, Oct 2016.

- Northouse, P. (2015): Leadership: theory and practice, $7^{\text {th }}$ ed, Thousand Oaks (CA): Sage Publications.

- Ofei, A., Paarima, Y., \& Barnes, T. (2020): Exploring the management competencies of nurse managers in the Greater Accra Region, Ghana, International Journal of Africa Nursing Sciences, Vol. (13),Pp. 100248.

- Pillay, R. (2011): The skills gap in nursing management in the South African public health sector. Public Health Nursing, Vol. (28) No. (2), Pp. 176-185.

- Pillay, R., (2009): perceived competences of nurse managers: a comparative analysis of the public and private sector in South Africa. African Journal of business Management Vol. (3) No. (9), Pp. 496503.

- Raup, G.H. (2008): the impact of ED nurse manager leadership style on staff nurse turnover and patient satisfaction in academic health center hospitals, Journal of Emergency Nursing,P. 403,404. Retrieved on January 4, 2021 from http://www.sciencedirect.com. dlibrary.zu.edu.eg/science ob=ArticleURL\&_udi=B6WJ5-4SRDFB4-

- Saleh, U., O'Connor, T., A-Subhi, H., Alkattan, R., Al-Harbi, S., \& Patton, D. (2018): The impact of nurse managers' leadership styles on ward staff, British Journal of Nursing, Vol. (27) No. (4). Retrieved on January 4, 2021 from https://www.researchgate.net/profile/Hattan Alsubhi/publication/323343723 The impact of nurse managers\%27 leadership_styles_on_ward_s taff/links/5aa1326f45851543e639e2c0/The-impactof-nurse-managers-leadership-styles-on-wardstaff.pdf

- Scoble, K.B.; Russell, G. \& Vision (2020), part I: Profile of the future nurse leader. Journal of Nursing Administration. 2003, 33, 324-330. [CrossRef]

- Shirey, M.R., Ebright, P.R., \& McDaniel, A. (2008): Sleepless in America: nurse managers cope with stress and complexity, Journal of Nursing Administration, Vol. (38) No. (3), Pp.125-131.

- Stobinski, T., (2011): competency and work environments among military and civilian perioperative registered nurses: predictive model, Published Doctor of Philosophy, Thesis in healthcare science, Cypress, California,Pp. 1-208.

- The American Organization of Nurse Executives (2015): Nurse Manager Competencies.
Chicago,IL:Author ,Accessibleat :http://www . aone.org /resources/nurse-leadercompetencies.shtml.

- Trivellas, P., \& Reklitis, P. (2014): Leadership competencies profiles and managerial effectiveness in Greece, Procedia Economics and Finance, Vol. (9), Pp. 380-390.

- Wendler, M., Olson-Siticki, K., \& Prater, M., (2009): Succession planning for RN_s: implementing a nurse management internship, Journal of Nursing Administration, Vol.(39) No.(7/8),Pp.326-333.

- Yang, L., Cui, D., Zhoe, Q., \& Shen, S., (2014): perspectives from nurse managers on informatics competencies, The scientific world Journal volume (2014) Article Id: 3917141:1- 